ship of the Association embraces independent wholetime consulting scientists in the United Kingdom in all fields of science and technology other than medicine and civil, mechanical and electrical engineering. The founding members are mostly chemists and biologists, but physics and other sciences are expected to be represented soon. The new Association will operate in close collaboration with the Royal Institute of Chemistry and other professional institutes, and with organizations concerned with the co-ordination of British efforts in research, production and marketing. The following officers of the Association have been elected: Chairman, Dr. J. G. Davis; Hon. Treasurer, Dr. G. W. Ferguson; Hon. Secretary, W. H. Stevens, to whom inquiries can be addressed at 15 Hawthorne Road, Bromley, Kent.

\section{The Leopoldina German Academy of Sciences: \\ Elections}

The Deutsche Akademie der Naturforseher Leopoldina, Halle, recently elected the following new members, in the sections indicated: Anatomy, Prof. Stefan Krompecher (Debrecen, Hungary), Prof. Dietrich Starck (Frankfurt am Main), Prof. Friedrich Wassermann (Lemont, Illinois), Prof. Wolfgang Bargmann (Kiel); Surgery, Prof. Willi Felix (Berlin), Prof. Karl Vosschulte (Giessen), Prof. Rudolf Zenker (Munich), Prof. Heinrich Kuntzen (Jena), Prof. Egbert Schwarz (Erfurt); Zoology, Prof. Manfred. Gersch (Jena); Mathematics, Prof. Heinz Hopf (Zurich), Prof. O.-H. Keller (Halle); History of Science and Medicine, Prof. Pedro Lain Entralgo (Madrid), Prof. N. A. Figurovskij (Moscow), Prof. P. A. Juschkewitsch (Moscow); Chemistry, Prof. Josef Anton Goubeau (Stuttgart); Botany, Prof. Bohumil Němec (Prague); Physiological Chemistry, Prof. John T. Edsall (Cambridge, Mass.); Odontology, Prof. Wilhelm Meyer (Göttingen); General Biology, Prof. Eduard Kellenberger (Geneva).

\section{"Some Palæomagnetic Investigations on Chinese Rocks"}

Dr. A. E. M. NaIRns has written in connexion with this communication in Nature of January 24, p. 254, stating that the present Fig. 1 is incorrect; the plotted points are mirror images of the actual points. On the original tracing, the graduations were drawn on one side of the sheet and the experimental points were, unfortunately, inserted on the other side; in preparing the block, the tracing was photographed from the wrong side.

\section{Announcements}

Prof. I. N. SNEddon, professor of mathematics in the University of Glasgow, has been awarded the Makdougall-Brisbane Prize for $1956-58$ of the Royal Society of Edinburgh for his work on thermal stresses published in the Proceedings of the Society within the period of the award.

THE Institution of Electrical Engineers is organizing an International Convention on Transistors and Associated Semiconductor Devices, which will be held at Earls Court, London, during May 21-27, together with an exhibition of scientific instruments employing such devices. Further information can be obtained from the Secretary, Institution of Electrical Engineers, Savoy Place, London, W.C.2.

THE second conference on Liquid Fuels, organized by the Institute of Fuel, is to be held at the Palace
Hotel, Torquay, during May 11-14, when twenty-one papers will be presented. Enrolment forms are available from the Secretary, Institute of Fuel, 18 Devon. shire Street, London, W.l, from whom further information can be obtained.

A JoINT meeting of the British Radio Frequency Spectroscopy Group and the Groupement AMPERE will be held in the Physics Department, Queen Mary College (University of London), Mile End Road, London, E.I, during April 1-3 on "The Study of Molecular and Atomic Motions in Solids and Liquids by Radiofrequency Methods". Further information can be obtained from Dr. J. G. Powles at the address given above.

The Conference of the Oil and Colour Chemists' Association will be held in Edinburgh during May 5-9. The technical sessions, under the general title "A Survey of Polymers", will be held in the North British Hotel under the chairmanship of Prof. E. L. Hirst. Registration forms and further information can be obtained from the general secretary, R. H. Hamblin, Oil and Colour Chemists' Association, Memorial Hall, Farringdon Street, Holborn, London, E.C.4.

A conference on Industrial Prospects in Nuclear Energy is being organized by the European Nuclear Energy Agency of the Organization for European Economic Co-operation. The conference, sponsored by the industrial federations of member and associated countries, and by the Council of European Industrial Federations, is to be held in Stresa, Italy, during May 11-14. Further information can be obtained from the European Nuclear Energy Agency, 38 Boulevard Suchet, Paris 16 .

A JOINT meeting of the AGARD Aeromedical and Flight Test Techniques and Instrumentation Panels will be held in Athens during May 11-15. The subject of survival and the reactions of the pilot to unforeseen hazards will be discussed. Special papers will be presented on : escape and survival techniques; medical and human engineering aspects of flight in non-conventional aircraft; and psychopathological stress problems in flying personnel, considered exclusively with reference to research required, or data obtained from research already carried out. Further information can be obtained from the Advisory Group for Aeronautical Research and Development, Organisation du Traité de l'Atlantique Nord, Palais de Chaillot, Paris $16^{\circ}$.

A JoINT symposium on Instrumentation and Computation in Process Development and Plant Design, organized by the Institution of Chemical Engineers, the Society of Instrument Technology and the British Computer Society under the ægis of the British Conference on Automation and Computation, is to be held at the Central Hall, Westminster, during May 11-13. Sessions will be devoted to improving the efficiency of existing processes; the design of new processes; the application of on-line computers; recent developments in instruments, on-line computers and computers for design; and the use of computer techniques in large and small companies. Preprints of the proceedings will be available; attendance is open to members of the sponsoring bodies and non-members on payment of a registration fee. Further details can be obtained from the General Secretary, Institution of Chemical Engineers, 16 Belgrave Square, London, S.W.1. 